\title{
Introduction to Philosophical Foundations of Contract Law
}

Gregory Klass

Georgetown University Law Center, gmk9@law.georgetown.edu

This paper can be downloaded free of charge from:

https://scholarship.law.georgetown.edu/facpub/1326

http://ssrn.com/abstract=2410381

Gregory Klass, Introduction to Philosophical Foundations of Contract Law, in PHILOSOPHICAL FOUNDATIONS OF CONTRACT LAW (G. Klass, G. Letsas \& P. Saprai, eds., Oxford University Press, forthcoming)

This open-access article is brought to you by the Georgetown Law Library. Posted with permission of the author. Follow this and additional works at: https://scholarship.law.georgetown.edu/facpub

Part of the Contracts Commons, and the Law and Economics Commons 


\section{Introduction to Philosophical Foundations of Contract Law Gregory Klass \\ March 2014}

This Introduction to Philosophical Foundations of Contract Law (Gregory Klass, George Letsas \& Prince Saprai eds., Oxford University Press, forthcoming) describes the field of contract theory and locates the essays in the volume within that field. The volume includes chapters from Aditi Bagchi, Randy Barnett, Lisa Bernstein, Mindy Chen-Wishart, Charles Fried, Avery Katz, Dori Kimel, Gregory Klass, George Letsas and Prince Saprai, Daniel Markovits, Liam Murphy, David Owens, J.E. Penner, Margaret Jane Radin, Joseph Raz, Stephen Smith, and Charlie Webb.

Contract theory is not one thing, but a collection of related inquiries. There is variety both in the questions theorists ask and in the methods they use to answer them. Among the questions are: What is distinctive about contract law? What are its core concepts? For what purpose do we enforce contracts? What justifies their enforcement? Given one or another function or justification, what should the rules of contract law be? What moral or political principles are relevant to the enforcement of contracts? There is also variety in method. Principled arguments of contract start from above. They ask first what justifies having a law of contract, and from that derive what the rules of contract law should be. Interpretive arguments begin from below. They examine the contract law we have, then ask what functions and justifications provide the best account of the practice. Critical analyses look for hidden purposes or unintended consequences, such as contract law's role in legitimizing or reproducing power relationships. Theorists also use a variety of analytic tools. These include moral and political theory, conceptual analysis, sociological theory, interpretation, neoclassical economic analysis and empirical psychology.

This introduction sketches the field and locates in it the chapters that follow. We have organized those chapters into two large groups: essays that focus on general theoretical questions and essays that focus on more specific doctrinal questions. But this is a rough cut at best, and only one way to divide things up. Because they vary along multiple dimensions, contract theories cannot be ordered around or along any single line. So this Introduction will zigzag a bit. 
It will help to define a few technical terms. Laws and collections of laws are instruments that society can employ to achieve one or more purposes. The purpose or purposes a law serves constitute its function. Because laws involve the deployment of collective resources and are ultimately backed by state coercion, they also require justification. That justification, if it exists, can be found in the moral, political or other principles that render the use of collective resources and state coercion permissible. ${ }^{1}$ Finally, it is sometimes argued that distinct areas of law, such as the law of contract, have an internal logic or core set of commitments. Just as a language has a grammar, contract law might have basic rules or commitments that structure the practice as a whole. This immanent logic, if it exists, is contract law's conceptual structure. Noncritical general theories of contract typically focus on one or more of contract law's function, its justification and its conceptual structure.

Much contract theory occupies itself one way or another with the relationship between contracts, which create legal obligations, and promises, which create moral ones. Contract law itself uses the language of promising. Courts and commentators regularly refer to the parties as "promisor" and "promisee," and the Restatement (Second) of Contract opens by saying that a contract is "a promise or set of promises for the breach of which the law gives a remedy, or the performance of which the law in some way recognizes as a duty." ${ }^{2}$ And no matter what words the law uses, there are obvious similarities between contracts and promises. Both are largely content independent, voluntarily acquired obligations owed to a particular person or persons.

Saying all that does not yet say what the relation between the legal obligation and the moral one is. One answer is that contract law functions to enforce certain promises. In contemporary Anglo-American scholarship, the thesis is most closely associated with Charles Fried's 1981 book, Contract as Promise. Fried's chapter in this volume updates that theory in light of subsequent work in the field. As Fried points out, dominant trends in contract theory have changed considerably in the past thirty years. The reliance-based and critical approaches that ruled when he wrote the book have been supplanted by economic analysis, corrective justice, and new autonomy theories. Fried's chapter discusses the relationship between his approach in Contract as Promise and subsequent work in the field. And he uses his chapter to provide new thoughts on topics such as the common law's preference for expectation damages, the consideration doctrine,

\footnotetext{
${ }^{1}$ As Charlie Webb puts the point in this volume, "even where the law's technical rules are determinate and neither require nor invite [appeal to value judgments], these source-based norms earn a place in our reasoning and decision-making only on the back of norms which get there on the merits." Charlie Webb, Contract as Fact and as Reason, in PHILOSOPHICAL FOUNDATIONS OF CONTRACT LAW [MS at 1] (Gregory Klass, George Letsas \& Prince Saprai eds., 2014).

${ }^{2}$ Restatement (SECOND) OF CONTRACTS $§ 1$ (1983).
} 
unconscionability, the mitigation rule, contract interpretation, and the objective theory.

The claim that contracts just are legally enforceable promises has led many contract theorists back to moral theory and the analysis of promissory obligations. Fried, for example, argues that the institution of promising, and by extension contract, is built "on the deeper morality of trust and respect for persons." ${ }^{3}$ Three chapters in this book focus on the morality of promising. Although they make different claims, each recommends paying attention not only to the new obligations a promisor acquires through her promise, but also to the normative interests or obligations of the promisee.

David Owens asks whether promises are properly characterized as transferring something from the promisor to the promisee. He argues against the common claim that a promise transfers the right to performance-that " $[b] y$ promising, I transfer my ... entitlement to act within a certain range of options, thereby giving that power to others." ${ }^{4}$ Appealing to Hume's point that the mere fact of having a right does not entail the power to alienate or transfer it, Owens argues that right-transfer theories cannot explain why promises bind. In Owens's view, the effect of a promise is rather to give the promisee the power to determine the promisor's moral obligations by deciding whether to insist on performance or to release the promisor from her obligation. Promises thereby serve what Owens calls the promisee's "Authority Interest." "By postulating an interest in the normative item that the promisee acquires we can identify the source of a promise's binding force." ${ }^{5}$

Joseph Raz's chapter explores several aspects of the reasons promises generate. Promises are generally content independent: the reason they bind does not depend on the act promised. Some acts, however, cannot be promised, such as selling oneself into slavery. Raz explains this fact by arguing that the power to promise exists only because, and to the extent that, it enhances our moral lives. There is no value to giving people the power to enslave themselves. Working from the same premise, Raz argues that promisors need not have the power to determine the strength of the reasons for performance that their promises create-to determine the strength of their promises. The fact that having the power to promise is valuable "does not mean that there is value in people being able to determine the strength of

${ }^{3}$ Charles Fried, The Ambitions of Contract as Promise, in PHILOSOPHICAL FOUNDATIONS OF CONTRACT LAW [MS at 8] (Gregory Klass, George Letsas \&

Prince Saprai eds., 2014).

${ }^{4}$ Gary Watson, Promises, Reasons and Normative Powers, in REASONS FOR ACTION 155, 170 (D. Sabel \& S. Wall eds., 2009), quoted in Owens MS at 17.

${ }^{5}$ David Owens, Does a Promise Transfer a Right?, in PHILOSOPHICAL Foundations OF CONTRACT LAW [MS at 18] (Gregory Klass, George Letsas \& Prince Saprai eds., 2014). For a more thorough discussion of this claim, see DAVID J. OWENS, SHAPING THE NORMATIVE LANDSCAPE (2012). 
the reasons that promises generate. ${ }^{\prime 6}$ Raz then asks how it is that the mere act of promising can create a new reason to act. He argues contra Owens that the reason to act is not a "bare reason" generated by the mere fact of the promise. Rather a promise gives the promisor a reason to perform because of the "normative assurance" that a promise provides the promisee, which is the promisee's opportunity to receive performance.

Dori Kimel also considers the normative position of the promisee. But where Raz and Owens emphasize the normative powers that a promise confers on the promisee, Kimel is interested in the promisee's moral duties in exercising those powers. Drawing from contract law, Kimel argues that promissory obligations are strict. Unless the promisor builds an excuse into the content of her promise, nonperformance is a breach of the promise, no matter what its reason or cause. This makes promising an especially risky business, in that a promisor might undertake obligations she later has reason to regret. If this is right, then "the capacity to self-create obligations owed to others may be thought of not only as a manifestation or an extension of personal autonomy, but also as something that can pose a particularly potent threat to it. ${ }^{7}$ In fact, we might do better without the power to promise. The threat is reduced, however, by moral obligations of the promisee to sometimes exercise the power to release the promisor from her promise. Kimel argues that "promises are typically made or exchanged in . . . the sort of relationships that tend to generate a wealth of relationship-specific norms capable of supplementing, competing with, altering or altogether defeating promissory norms." ${ }^{8}$ The promisee's nonpromissory obligations of friendship, for example, can require her to excuse nonperformance when the promisor is not at fault, thereby reducing the risk attached to the unwise promise.

For those who believe that contract law functions to enforce promissory obligations, such arguments about the structure and scope of the moral obligation are highly relevant to understanding the structure and scope of the corresponding legal obligation. (I argue below that they might be relevant to other contract theorists as well, for other reasons.) If promissory obligations are the reason for enforcing contracts, we need to know what promissory obligations are and what they entail.

But promissory theories of contract are not without their critics. The critics can be divided into two broad camps: those who agree with Fried that contract serves moral ends, but reject his account of those ends, and those who reject moral accounts of contract law altogether.

${ }^{6}$ Joseph Raz, Is There a Reason to Keep a Promise?, in PHILOSOPHICAL FOUNDATIONS OF CONTRACT LAW __, [MS at 1o] (Gregory Klass, George Letsas \& Prince Saprai eds., 2014).

${ }^{7}$ Dori Kimel, Promise, Contract, Personal Autonomy, and the Freedom to Change One's Mind, in PhILOSOPHICAL FOUNDATIONS OF CONTRACT LAW [MS at 3]

(Gregory Klass, George Letsas \& Prince Saprai eds., 2014).

${ }^{8} / d$. at [MS at 14$]$. 
Many who agree with Fried that contract serves moral ends do not agree with his claim that it serves to enforce promises. These theorists depart from Fried in two distinct ways. ${ }^{9}$ First, some hold that the legally relevant moral obligations are not, or not only, promissory obligations. In his contribution to this volume, James Penner argues that contracts are best understood as involving agreements rather than promises. ${ }^{10}$ Penner suggests several differences. First and foremost, whereas promises are unilateral acts, agreements are bilateral, involving active participation and commitment by all sides. In addition, agreements often arise in conditions where there is a preexisting obligation to coordinate behavior or a shared interest in accomplishing some project. And agreements are typically built on a shared foundation of mutual trust and an appreciation of one another's interests, whereas promises are often prompted by the promisee's mistrust of the promisor. On Penner's account, "promises are typically parasitic on prior agreements and are 'pathological' in the sense that they are typically only sought or given when a person already obliged is, for one reason or another, less than optimally likely to fulfill their obligation." ${ }^{11}$ If Penner is correct, we should look for a moral basis for the law of contract not in the morality of promises, but in the morality of agreements more generally. Such a shift could shed new light on doctrines such as the requirement of good faith, the frustration and impracticability defenses, and the mitigation rule.

Other theorists question whether contract law's function with respect to the parties' moral obligations is one of simple enforcement. Liam Murphy's chapter distinguishes three functions contract law might play with respect to the moral sphere. First, contract law might enforce the first-order moral obligation to perform, as Fried suggests. Second, contract law might enforce second-order obligations that come into being only after the wrong of breach, as corrective justice theories claim. Third, contract law might be deployed instrumentally to increase social welfare, attending to the parties' particular obligations to one another only as a means to that broader end. Murphy discusses examples of the first two approaches, which he argues do not succeed. Enforcement theories are difficult to square with the law's preference for expectation damages over specific performance, and they run contrary to a liberal suspicion of using state coercion "merely for the sake of improving a person's own welfare, or enforcing their obligations, or making them

\footnotetext{
${ }^{9}$ Both are discussed in Gregory Klass, Promise Etc., 45 Suffolk U. L. ReV. 695 (2012).

${ }^{10}$ Penner's chapter updates and extends his earlier work on the subject in J.E. Penner, Voluntary Obligations and the Scope of the Law of Contract, 2 LEGAL THEORY 325 (1996).

${ }^{11}$ J.E. Penner, Promises, Agreements, and Contracts, in PHILOSOPHICAL FOUNDATIONS OF CONTRACT LAW [MS at 18] (Gregory Klass, George Letsas \& Prince Saprai eds., 2014).
} 
more virtuous."12 Expectation-based corrective justice theories "offer[] no argument at all for the idea that all promisees have moral rights that it is the business of the law to protect." ${ }^{13}$ Reliance-based corrective justice theories can explain neither why the law provides recovery for reliance on promises but not other sorts of reliance, nor the law's preference for the expectation measure. This leaves instrumentalist approaches, which "will not try to track the moral duties and interests of parties to particular agreements but will rather take a broader view, finding the point of the institution in the overall social good it produces." ${ }^{14}$ Murphy's preferred instrumentalist approach is like economic analysis in that it identifies contract law's function as the promotion of social welfare. But Murphy takes a broader view of what constitutes social welfare. Whereas traditional economic analyses ask what remedies are likely to maximize the parties' joint profits, Murphy would ask what remedy is better for society as a whole, with a focus on contract law's role in supporting the social practice of making and keeping agreements.

Charlie Webb argues in his chapter that contracts necessarily give rise to promissory obligations, but that those obligations are not the reason for their legal enforcement. Contracts entail promises, according to Webb, because legal obligations claim to be moral obligations and so to voluntarily undertake a legal duty to perform a contract is also to voluntarily undertake a moral obligation to do so. "[I]f and in so far as contracts do involve the voluntary assumption of obligations - whatever their content-then these obligations are moral obligations." ${ }^{15}$ It does not follow, however, that the promise is the reason for legal enforcement. "Whatever reasons we may identify for regarding promises as obligation-creating may not be reasons to take them as creating legal rights and duties such as support state policing and intervention in the event of breach."16 Webb does not fully articulate a theory of legal enforcement, but suggests that the relationship to the theory of promises is complex. On the one hand, the conditions of contractual validity clearly do not track the conditions of promissory obligations. On the other, the law can help to inform promisors as to the scope of their obligations. The morality of promising, in Webb's account, is relevant to the theory of contract, but the latter "need neither begin nor end with an account of promissory obligation."17

Penner, Murphy and Webb do not deny that contract law might serve a moral function. They depart from Fried only in what each considers that function to

\footnotetext{
${ }^{12}$ Liam Murphy, The Practice of Promise and Contract, in PHILOSOPHICAL FOUNDATIONS OF CONTRACT LAW [MS at 12] (Gregory Klass, George Letsas \&

Prince Saprai eds., 2014).

${ }^{13}$ Id. at [MS at 20].

${ }^{14}$ Id. [MS at at 22].

${ }^{15}$ Webb, supra note 1 , at [MS at 14].

${ }^{16} / d$. at [MS at 17].

${ }^{17} / d$. at [MS at 19].
} 
be. Other theorists maintain that the function of contract law is not to be found in the parties' moral obligations at all. Like Fried, Randy Barnett is an autonomy theorist. But Barnett rejects promissory or other moral theories of contract. In this volume, he argues that Fried's promise theory can neither explain the objective approach to contract interpretation nor guide lawmakers as to the appropriate default rules. More fundamentally, Barnett, like Murphy, argues that the law has no business enforcing the private morality of promising. Barnett would not agree with Murphy, however, that the function of contract law is therefore to support the moral practice more broadly. Rather than focusing on parties' moral relationships, contract law should ask only whether the parties to a transaction have consented to legal enforcement-whether at the time of formation they intended to be legally bound. Both Fried and Barnett are autonomy theorists. But where Fried's promise theory views contract law as imposing duties based on the parties' autonomous moral act of promising, Barnett characterizes it as conferring on them the legal power to autonomously undertake legal obligations to one another, no matter what their moral relationship. ${ }^{18}$ For Barnett, "the private morality of promise resides in the realm of ethics," whereas "the morality of contract resides in the realm of justice." 19

Barnett's consent theory of contract reflects his principled commitment to a libertarian theory of legal entitlements. ${ }^{20}$ Other theorists provide other arguments for depicting contract as a sort of private legislative power that is independent of the parties' promise-based obligations. Dori Kimel has argued that contracts are not promises, but substitute for promises in situations where thicker forms of trust are not available. ${ }^{21}$ Michael Pratt has constructed a thought experiment to demonstrate how one might undertake contractual obligations while at the same time effectively abjuring promissory ones. ${ }^{22}$

Another largely amoral account of contractual obligations can be found in economic analyses of contract law. The application of economic tools to legal questions is more common in the United States than elsewhere in the Englishspeaking world. Two chapters in this book provide windows into the approach. Avery Katz's chapter describes the basic concepts of economic legal analysis, such as the distinction between positive and normative economic analysis, how

\footnotetext{
${ }^{18}$ For more thoughts on theories of contract law as duty-imposing and as powerconferring, see Gregory Klass, Three Pictures of Contract: Duty, Power and Compound Rule, 83 N.Y.U. L. REV. 1726 (2008).

${ }^{19}$ Randy E. Barnett, Contract Is Not Promise; Contract Is Consent, in PHILOSOPHICAL FOUNDATIONS OF CONTRACT LAW [MS at 16] (Gregory Klass, George Letsas \& Prince Saprai eds., 2014).

${ }^{20}$ See Randy E. Barnett, THe StruCture Of Liberty: Justice AND tHe RULE OF LAW (2000).

${ }^{21}$ Dori Kimel, From Promise to CONTRACt: TOWARD A Liberal THEORY OF CONTRACT (2002).

${ }^{22}$ Michael G. Pratt, Contract: Not Promise, 35 FlA. St. U. L. Rev. 801 (2008).
} 
economists model decision making, and efficiency. Katz suggests several reasons to think that the normative economic analysis of contract law makes special sense, especially when it comes to contracts between sophisticated parties.

In commerce, it is easier to value things in monetary terms and to calculate costs and benefits; and economic gain is usually the motivation for the transaction. In addition, contractual obligations are typically undertaken deliberately, at arms' length, and with managerial oversight if not professional legal assistance. The economic model of rational choice provides a more plausible account in such settings than it does when applied to less calculating actors such as negligent tortfeasors, divorcing spouses, criminals, or residential tenants. ${ }^{23}$

Moreover, because such contracts involve exchanges understood by sophisticated parties and to which they must consent, gains in overall efficiency are likely to be shared among them to make everyone better off. After mapping out three distinct approaches to economic analysis of the law, Katz provides the reader with examples of economic analyses of formation rules, the choice between private enforcement and state enforcement, contract interpretation, and the measure of damages for breach. Katz concludes with a discussion of where economic analysis stands with respect to other jurisprudential approaches to contract law. And he suggests that whether or not lawyers, judges or legislators accept the prescriptive claims of normative economic analysis, they can and should employ the tools of economic analysis when performing their various roles.

My own chapter focuses on the best-known and most controversial example of the economic analysis of contract: the theory of efficient breach, which first appeared in the literature more than forty years ago. After recounting a simple version of the theory and some common noneconomic criticisms of it, I describe four ways in which subsequent economic accounts have rejected and moved beyond the simple theory. Many non-economist critics of efficient breach, it turns out, are criticizing a theory that no serious economist would defend. But contract theorists should still pay attention to efficient breach theory. A more sophisticated version of the theory reveals three distinctive features of contract law that noneconomic theories often overlook: "remedies often affect prices; parties often prefer efficient remedies; and lawmakers must decide whether, when or how parties might choose the remedy." ${ }^{24}$ This claim is consistent with Murphy's suggestion that any instrumentalist theory should take economic analysis into

${ }^{23}$ Avery W. Katz, Economic Foundations of Contract Law, in PHILOSOPHICAL FOUNDATIONS OF CONTRACT LAW __, [MS at 8] (Gregory Klass, George Letsas \& Prince Saprai eds., 2014).

${ }^{24}$ Gregory Klass, Efficient Breach, in PhILOSOPHICAL Foundations OF CONTRACT LAW___, [MS at 2] (Gregory Klass, George Letsas \& Prince Saprai eds., 2014). 
account because economic analysis of the law offers "the only sustained attempt at explaining how legal rules affect behavior." ${ }^{25}$

Like consent theories, economic accounts view contract law as functioning primarily to confer on parties a private legislative power, rather than as taking account of independently acquired moral obligations. On these theories, contract law does not serve to enforce, support, or otherwise respond to the parties' moral obligations. These theories do, however, treat contract as a legal analog to the moral power of promising. Both contract and promise give persons the ability to voluntarily undertake new obligations-one legal, the other moral. This similarity provides an independent reason for contract theorists to pay attention to promise theory, whether or not they think that the point of contract is to enforce promisebased obligations. Thus Kimel, who believes that contracts are not promises but substitute for them, draws at the end of his chapter an analogy between contract and promise. Like promises, contracts can both expand autonomy and, when done wrongly, endanger it. Kimel suggests that this helps explain doctrines like the consideration requirement and the common use of money damages rather than specific performance. And Kimel's thoughts about a promisee's moral obligation to sometimes release a promisor find their counterpart in George Letsas and Prince Saprai's observations, discussed below, about a nonbreaching party's obligation to mitigate damages. Similarly, Owens's analysis in this volume of transfer theories of promise has implications for transfer theories of contract. Raz's observations about the limits on a promisor's power to decide the strength of her promise suggest ways of thinking about whether parties should have the power to specify the remedy for breach. And the Owens and Raz chapters both suggest that contract theorists might pay more attention to the legal powers of the promisee, such as waiver, demanding adequate assurance, affirmation, cancellation, and a suit for breach. In short, one need not be a promise theorist to think that a clear understanding of the morality of promising is likely to cast new light on the law of contract.

The moral theories discussed above largely assume a sphere of moral obligations that exists and can be specified independently of the law of contracts. Other theorists argue instead for an intrinsic and distinctive morality of contractone that might well be compatible with both consent and efficiency theories. Daniel Markovits has argued that contracts generate not promises but a distinctive form of moral relationship all their own. ${ }^{26}$ In his chapter in this volume, Markovits argues that, properly understood, the obligation of good faith that attaches to every contract exemplifies a more general moral relationship of solidarity that contracts produce. The case begins with an analysis of the outer bounds of the duty. The duty of good faith is, Markovits argues, both "thin (being limited to respect for an antecedently and independently agreed surplus allocation) and flexible (being open

\footnotetext{
${ }^{25}$ Murphy, supra note 12 [MS at 23].

${ }^{26}$ See Daniel Markovits, Contract and Collaboration, 113 YALE L.J. 1417 (2004).
} 
to any surplus allocation on which the parties have so agreed). ${ }^{27}$ On this interpretation, the duty is neither a separate obligation nor a gap-filling rule, but simply the obligation to abide by the parties' shared intentions with respect to their agreement. A party's duty of good faith is her obligation not to "abandon her contractual intentions, including the intention to adjust to unanticipated contingencies in a fashion that secures the success of the contractual collaboration's shared plan." ${ }^{28}$ This attitude and the distinctive form of solidarity it generates together define a moral perspective that underlies not only the marketplace, but liberal democratic societies more generally.

Markovits's project is to describe a moral relation distinctive of contractual relationships. That project involves abstracting from the various other moral relations in which contracting parties might find themselves. Thus Markovits goes so far as to suggest that "contract possesses the power to launder injustice, creating legitimate entitlements between parties where previous there were none." ${ }^{29}$ Several other contributors emphasize instead ways in which nonvoluntary moral obligations apply to contracting parties in their relations with one another. Without denying that contracts are distinguished by voluntary obligations-moral, legal or both-these authors argue that contracts also implicate other values or moral principles, and that a complete account of contract law must attend to those values or principles as well.

Aditi Bagchi argues that as a result of the exclusive focus on promise, "contract is not regarded as an elaboration of the standards of fairness in private exchange, which might plausibly involve a range of moral principles, but only a deconstruction of the morality of promising. ${ }^{30}$ Bagchi, however, is interested in distributive justice, and especially the fact that the background conditions of many contracts involve unjust distribution. She allows that contract law is in several respects a poor tool for doing distributive justice. Contracts enforce particular agreements, whereas distributive injustice is systematic; the consent of the disadvantaged party might seem to vitiate broader claims of distributive justice; and there is a real worry that the attempts to regulate inequality in exchange will backfire and impose greater harms on disadvantaged parties, whether by producing iniquitous terms elsewhere in the transaction or by excluding disadvantaged parties from the market. But even granting these worries, Bagchi argues that distributive injustices should sometimes inform when society chooses to provide a party with the benefit of legal enforcement. And, she argues, a complete account of contract

${ }^{27}$ Daniel Markovits, Good Faith as Contract's Core Value, in PHILOSOPHICAL FOUNDATIONS OF CONTRACT LAW __, [MS at 14] (Gregory Klass, George Letsas \& Prince Saprai eds., 2014). MS at 14.

${ }^{28}$ Id. at [MS at 25].

${ }^{29}$ Id. at [MS at 24].

${ }^{30}$ Aditi Bagchi, Distributive Justice and Contract, in PHILOSOPHICAL FOUNDATIONS OF CONTRACT LAW __, [MS at 1] (Gregory Klass, George Letsas \& Prince Saprai eds., 2014). 
law must attend to distributive justice, since "some of the background duties that infuse contract are derivative from principles of distributive justice." ${ }^{31}$

As already mentioned, George Letsas and Prince Saprai argue in their chapter that the mitigation rule is best explained by obligations that are neither promissory nor specific to contracts. They maintain that the rule is not, as Charles Fried has argued, grounded in a duty of altruism generated by the parties' relationship, but that it is a special application of a general principle of fairness. Although the nonbreaching party has no altruistic duty to avoid losses, it would be unfair for her to claim compensation for losses that she could have avoided without undue burden. Letsas and Saprai argue that the doctrinal elaborations of the mitigation rule found in English law largely conform to the requirements of the fairness principle. And, they argue, the appeal to fairness provides answers to Seana Shiffrin's claim that the mitigation rule is inconsistent with promissory morality and to Dori Kimel's argument that the mitigation rule is grounded in the harm principle. "[S]eemingly divergent doctrines of contract law can be justified if one considers the interaction between the promise principle and other moral principles." ${ }^{\prime 2}$

Mindy Chen-Wishart's chapter also describes a "conceptual space for the operation of principles beyond consent" in contract law. ${ }^{33}$ Chen-Wishart's analysis focuses on vitiating factors such as incapacity, unconscionability, mistake, misrepresentation and duress, or what in the United States are commonly termed "formation defenses." She argues that these doctrines are structured to impose responsibility for reasonable expectations and reliance, to ensure fair dealing and withhold state support for exploitation, to advance both corrective and distributive justice, to advance community values, and to ensure administrability. After considering and rejecting consent-based accounts of these rules, Chen-Wishart argues that autonomy is a defeasible principle-one that can be overridden by other principles, policies and values. Against the charge that such pluralism provides no guidance for courts when principles recommend different outcomes or rules, Chen-Wishart argues that the several values she identifies are complementary. More specifically, because "[t]he value of personal autonomy depends on the worthiness of its exercise," respect for autonomy requires also attending to the values that establish that worthiness. ${ }^{34}$

Letsas and Saprai's and Chen-Wishart's chapters each argues that consentor promise-based principles fail to fully explain or justify the rules of contract law

\footnotetext{
${ }^{31}$ Id. at 8 .

${ }^{32}$ George Letsas \& Prince Saprai, Mitigation, Fairness and Contract Law, in PhILOSOPHICAL FOUNDATIONS OF CONTRACT LAW__, [MS at 20] (Gregory Klass, George Letsas \& Prince Saprai eds., 2014).

${ }^{33}$ Mindy Chen-Wishart, The Nature of Vitiating Factors in Contract Law, in PHILOSOPHICAL FOUNDATIONS OF CONTRACT LAW __, [MS at 1] (Gregory Klass, George Letsas \& Prince Saprai eds., 2014).

${ }^{34} I d$. at [MS at 23].
} 
we find in the world around us. To the extent that their arguments start from the contract law we have, they can be classified as broadly interpretive. Stephen Smith's chapter on remedies also adopts an interpretive approach, though here Smith is interested less in the moral basis of contract law than in its function. ${ }^{35}$ Smith poses a basic question about contract remedies: Is the reason for granting the remedy the parties' first-order duty to perform, as suggested by many corrective justice theories, or is it the fact that a wrong has been committed by that duty's breach? Smith argues for the latter interpretation, based on the structure and framing of common law damage awards, as well as more particular remedial rules such as the privity requirement and the ready availability of consequential damages. More broadly, the law does not impose a duty to pay damage upon breach, but does so only after a court ruling that identifies the appropriate remedy for the wrong. Together with additional theoretical considerations, these facts suggest that "the aim of damages, in broad outline, is to provide redress for wrongs, ${ }^{\prime 36}$ and "damages orders create rather than confirm duties. ${ }^{\prime 37}$ Like a fine or punitive damages, compensatory damages for breach mark that a wrong has been committed and shift responsibility for the consequences of that wrong to the wrongdoer. "[D]amages are the private law equivalent of punishment." ${ }^{38}$

Smith's analysis exemplifies a tradition of interpretive and conceptual legal analysis that is stronger in Commonwealth countries than in the United States. Such scholarship aims to uncover the law's immanent logic and the legal principles that a common law judge might rely on to extend an existing rule to a novel case or to resolve inconsistencies within the doctrine. To US theorists and jurists steeped in the Legal Realist tradition, such arguments might appear formalist. But they can also figure into theories of the function or justification of contract law by suggesting alternative purposes the law might serve, and providing a better understanding of which theories fit with existing practice and which recommend revising it.

Much in contract theory depends on the choice of examples or paradigm cases. Those who find the function of contract in the parties' moral obligations often focus on relatively low-stakes agreements between natural persons. Those who think of contract primarily as a private legislative power are more likely to emphasize high-stakes transactions between sophisticated parties, especially firms. (Barnett, whose consent theory is grounded in libertarian considerations, is an exception to the latter generalization.) The importance of examples can also be seen in the differences between the contributions of Lisa Bernstein and Margaret Jane Radin.

${ }^{35}$ Smith's interpretive argument for a rights-based promise theory of contract can be found in STEPHEN A. SMITH, CONTRACT THEORY (2004).

${ }^{36}$ Stephen A. Smith, Remedies for Breach of Contract: One Principle or Two?, in PhILOSOPHICAL FOUNDATIONS OF CONTRACT LAW __, [MS at 18] (Gregory Klass, George Letsas \& Prince Saprai eds., 2014).

${ }^{37} I d$. at [MS at 20].

${ }^{38} / d$. at [MS at 21]. 
Working within a broadly instrumentalist framework, Lisa Bernstein explores the interaction between legal obligations and extralegal forms of assurance such as repeat-play, reputation, and nonlegal norms. Her thesis is twofold. First, she argues against attempts to give legal effect to customary business norms, commonly referred to as "trade usage." Using a mix of empirical and informal economic analysis, Bernstein argues that in many economic spheres there is no widespread agreement on trade usage, that where trade usage does exist it is often difficult to verify in court, and that most sophisticated parties do not want courts to use trade usage to interpret their agreements. Second, Bernstein criticizes courts' use of two other types of context evidence: course of dealings-the parties' actions in earlier similar transactions-and course of performance-how the parties performed under the contract at issue. One problem with using such evidence is that every deviation from contractual requirements then has the potential to change the parties' legal obligations. That result is likely to deter the flexibility in performance that many contemporary transactions require, which in turn can prevent the parties from utilizing "extralegal commitments backed only by reputation bonds and other types of nonlegal sanctions." ${ }^{139}$ Another problem is that the use of such evidence increases a large organization's costs of doing business, as it must constantly monitor employees' actions to guard against unwanted changes to the organization's legal obligations. Again, Bernstein collects a range of empirical evidence that, for these and other reasons, sophisticated parties commonly craft their contracts to exclude such evidence from the interpretation of their contracts. If Bernstein is correct, no matter what the social interest in enforcing the obligations generated by parties' actual expectations and agreements, sophisticated parties do not want such enforcement. And if given the opportunity, they will contract out of it.

Bernstein's arguments are an example of the new formalism in contract theory. "New" here refers not to the theory's vintage. The arguments have now been around for over twenty years. ${ }^{40}$ It is used, rather, to distinguish the theory from an older formalism often associated with Christopher Columbus Langdell and Samuel Williston and sharply criticized by the first generation of Legal Realists. In contrast to the old formalism, the new formalism employs instrumentalist, economic and empirical arguments, putting it squarely in the Realist camp.

Margaret Jane Radin's chapter also adopts a broadly empirical and Realist approach, but emphasizes the costs of formalism in other contracting contexts.

\footnotetext{
${ }^{39}$ Lisa Bernstein, Merchant Law in a Modern Economy, in PHILOSOPHICAL FOUNDATIONS OF CONTRACT LAW [MS at 29] (Gregory Klass, George Letsas \& Prince Saprai eds., 2014).

${ }^{40}$ For an early example, see Robert E. Scott, A Relational Theory of Default Rules for Commercial Contracts, 19 J. LEGAL STUD. 597 (1990); for a recent example, see Ronald J. Gilson, Charles F. Sabel \& Robert E. Scott, Contract and Innovation: The Limited Role of Generalist Courts in the Evolution of Novel Contractual Forms, 88 N.Y.U. L. REV. 170 (2013).
} 
Where Bernstein is interested in the rules for interpreting valid contracts, Radin focuses on the rules that determine whether a contract is valid. And where Bernstein limits her analysis to contracts between sophisticated parties, Radin considers transactions with nonsophisticates. Radin's topic is transactions in which an unsophisticated party agrees to a form contract provided on a take-it-or-leave-it basis by a sophisticated party that engages in many similar transactions. Common examples of such "boilerplate" contracts include employment contracts, consumer contracts, and the licensing agreements to which users "agree" every time they choose to install or update a piece of software. The enforcement of these agreements in the United States turns almost entirely on the nonsophisticated party's formal act of agreement, without a significant inquiry into the quality of her consent or the fairness of the terms. The reason, Radin argues, is that in the United States the only mechanism for policing these agreements is the judicially developed unconscionability doctrine. After identifying several problems with that approach, Radin suggests a nonformalist framework for determining when to enforce boilerplate terms. Here Radin emphasizes not only the potential costs to the individual who agrees to unfavorable terms, but also the costs of the "large-scale remedy-deletion" ${ }^{\prime 1}$ as terms proliferate, especially with respect to entitlements that are "components of public regimes underwritten by the polity for the sake of the structure of the polity itself." ${ }^{42}$ Radin argues that we should not think of such entitlements as either alienable or inalienable. Rather, we should consider making some entitlements more difficult to sell than others. And if a contract purports to transfer such an entitlement, the legal rule should examine not only the quality of consent and the effects for the parties, but also the social and political effects of widespread use of the term at issue. Public structures such as tort, contract and antidiscrimination law "should not be undermined by individual contracts, especially not when the contracts themselves may in fact be non-contracts." 43

Several chapters in this book address metatheoretical issues, such as what is the question contract theorists should be asking and what sorts of arguments, analyses or data can succeed in answering it. Charlie Webb spends a number of pages arguing for the possibility of nonevaluative accounts of legal practices generally.

Legal practice ... provides us with two distinct objects of inquiry: (1) we can inquire into how, as a matter of fact, decisions are and have been made within a particular community or across a set of communities; and (2) we can adopt the perspective of those acting within such a community, setting

${ }^{41}$ Margaret Jane Radin, An Analytic Framework for Legal Evaluation of Boilerplate, in Philosophical Foundations of COntract LaW __, [MS at 4] (Gregory Klass, George Letsas \& Prince Saprai eds., 2014).

${ }^{42}$ Id. at [MS at 38].

${ }^{43}$ Id. at [MS at 38-39]. 
out to answer the same practical questions they face, identifying how they really ought act. $^{44}$

Webb deploys the possibility of nonevaluative legal theory to argue against the relevance of interpretive theory along the lines Dworkin describes and Smith and others practice. $^{45}$

[W] hile we shouldn't deny that an inquiry into reasons which might be said to support these practices has the option not to consider those reasons on their merits, once we abandon the search for the reasons which have in fact guided these practices, it's not clear why this is an option anyone would want to take. ${ }^{46}$

Other chapters also address what makes for good contract theory. Murphy argues that contract theorists should attend to the normative structure of existing contract laws, but should not treat that structure as a limit on the contract law we might want. Katz's chapter on economic analysis is as much about the method of doing contract theory as it is about the purpose or design contract law. Bernstein's chapter illustrates ways contract theorists might engage more with empirical work. And Murphy and I both argue that they should engage more with economic analyses of contract.

In our attempt to capture both the substantive and methodological variety of contract theory within the space of a single volume we have had to omit examples of each. If Oxford University Press had given us two volumes for this project, we would also have included examples of reliance theories, ${ }^{47}$ of corrective justice theories, ${ }^{48}$ of civil recourse theories, ${ }^{49}$ and of transfer theories. ${ }^{50}$ We would

${ }^{44}$ Webb, supra note 1, at [MS at 4] (footnote omitted).

${ }^{45}$ RONALD DWORKIN, LAW'S EMPIRE (1986). Jules Coleman, no Dworkinian, also defends the relevance of interpretive legal theory. JULES L. COLEMAN, THE PRACTICE Of Principle: In Defence Of A Pragmatist ApProaCh TO LeGal TheOry 3-12 (2001). ${ }^{46}$ Webb, supra note 1 , at [MS at 8$]$.

${ }^{47}$ The classic reliance theorist was P.S. Atiyah. See, e.g., P.S. Atiyah, Contracts, Promises and the Law of Obligations, 94 LAW Q. REV. 193 (1978). For more recent work along these lines, see T.M. Scanlon, Promises and Contracts, in THE THEORY OF CONTRACT LAW: NeW ESSAYS 86 (Peter Benson, ed. 2001).

${ }^{48}$ See, e.g., Ernest J. Weinrib, Punishment \& Disgorgement as Contract Remedies, 78 CHI.-Kent L. ReV. 55 2003); Curtis Bridgeman, Reconciling Strict Liability with Corrective Justice in Contract Law, 75 FORDHAM L. REV. 3013 (2007).

${ }^{49}$ See, e.g., Nathan B. Oman, Consent to Retaliation: A Civil Recourse Theory of Contractual Liability, 96 IOWA L. REV. 529 (2011).

${ }^{50}$ See, e.g., Andrew S. Gold, A Property Theory of Contract, 103 Nw. U. L. Rev. 1 (2009). 
also have sought out examples of critical theories of contract, ${ }^{51}$ recent attempts to apply behavioral economics and the methods of empirical psychology to contract law, ${ }^{52}$ and theories that draw from major philosophical frameworks such as those of Hegel or Aristotle. ${ }^{53}$ We believe, however, that the selection presented here will provide the reader with a general introduction to the field. And we are enormously grateful to the contributors to this volume, whose novel works are significantly advancing our understanding of contract.

${ }^{51}$ See, e.g., Duncan Kennedy, Form \& Substance in Private Law Adjudication, 89 HARV. L. ReV. 1685 (1976); Robert W. Gordon, Unfreezing Legal Reality: Critical Approaches to Law, 15 FLA. ST. U. L. ReV. 195 (1987); Patricia J. Williams, Alchemical Notes: Reconstructing Ideals from Deconstructed Rights, 22 HaRV. C.R.-C.L. L. REV. 401 (1987).

${ }^{52}$ See, e.g., Melvin Aron Eisenberg, The Limits of Cognition and the Limits of Contract, 47 Stan L. ReV. 213 (1995); Tess Wilkinson-Ryan \& David A. Hoffman, Breach is for Suckers, 63 VAND. L. REV. 1001 (2010).

${ }^{53}$ See, e.g., Peter Benson, The Unity of Contract Law, in THE THEORY OF CONTRACT LAW: NEW ESSAYS 118 (Peter Benson, ed. 2001); James Gordley, Contract Law in the Aristotelian Tradition, in THE THEORY Of CONTRACT LAW: NeW ESSAYS 265 (Peter Benson, ed. 2001). 